\title{
Numerical Simulation of Flood Routing using the Simplified Saint Venant Equations in Rectangular Channels
}

\author{
Bambang Agus Sulistyono ${ }^{1 *}$, Samijo $^{2}$ and Dian Devita Yohanie ${ }^{3}$ \\ 1,2,3 Department of Mathematics Education, Faculty of Health and Science, \\ Universitas Nusantara PGRI Kediri, Indonesia \\ Email: *bb7agus1@unpkediri.ac.id, sammatunp@gmail.com, diandevitay17@gmail.com
}

\begin{abstract}
Floods, which cause a lot of damage, are a natural phenomenon that often occurs during the rainy season. Flood occurs because the discharge entering the channel exceeds the channel capacity. If the discharge data in the upstream area that will enter the channel is known, we can determine the flow behavior in the downstream area using a mathematical model. In this study, we proposed using simplified Saint Venant equations to simulate the flow routing in a prismatic channel with a rectangular section. This model is solved numerically using the finite difference method. Here, the numerical scheme used succeeds in simulating the flow behavior in the channel due to the discharge entering it. The simulation results show that the discharge entering the channel will propagate downstream with decreasing discharge quantity. Information on the amount of discharge at locations along the channel is useful as supporting data for flood control and prevention systems that will be conveyed to residents along the channel.
\end{abstract}

Keywords: flood routing; prismatic channel; Saint Venant Equations; finite difference method.

\begin{abstract}
Abstrak
Banjir yang menimbulkan banyak kerusakan merupakan fenomena alam yang sering terjadi pada musim bujan. Banjir terjadi karena debit yang masuk ke dalam kanal melebibi kapasitas kanalnya. Jika data debit di daerah bulu yang akan masuk ke dalam kanal diketabui, maka kita dapat menentukan perilaku aliran di daerab bilir dengan menggunakan model matematika. Dalam studi ini, kami mengusulkan untuk menggunakan persamaan Saint Venant yang disederbanakan untuk mensimulasikan penelusuran aliran pada saluran prismatik dengan penampang persegi panjang. Model ini diselesaikan secara numerik dengan menggunakan metode beda bingga. Di sini, skema numerik yang digunakan berhasil mensimulasikan perilaku aliran pada saluran akibat debit yang masuk. Hasil simulasi menunjukean babwa debit yang masuk ke saluran akan merambat ke bilir dengan kuantitas debit yang semakin berkurang. Informasi jumlah debit di lokasi sepanjang saluran ini berguna sebagai data pendukung pada sistem pengendalian dan pencegahan banjir yang akan disampaikan kepada penduduk. di sepanjang kanal.
\end{abstract}

Kata kunci: penelusuran banjir, saluran prismatik; persamaan Saint Venant; metode beda bingga.

\section{INTRODUCTION}

Floods can cause damage to agricultural areas, industrial areas, and cities. Floods also disrupt human activities, damage facilities and infrastructure, loss of property and even human lives. In general, flooding occurs because the channel is unable to accommodate the discharge entering the channel. To prevent damage from flooding, water structures such as embankments, weirs, etc., are usually constructed at several locations along the channel. To design a water structure, information is always required about the amount of discharge at the

Submitted February $16^{\text {th }}, 2021$, Revised May 13 $3^{\text {th }}, 2021$, Accepted for publication May $13^{\text {th }}, 2021$.

This is an open access article under CC-BY-SA license (https://creativecommons.org/licence/by-sa/4.0/) 
location where the water structure will be erected. Information on the amount of discharge is essential to determine the strength of the water structure to be built so that it does not break.

Many ways or methods can determine the amount of discharge at the required locations along the channel. In this study, we propose using a mathematical model that can describe the flow behavior in the channel in the form of the Saint Venant equations. The Saint Venant equations are composed of two hyperbolic partial differential equations: the continuity and momentum equations. This model is a nonlinear system of equations, and the analytical solution has not been found. Therefore, in practice, some researchers simplify the Saint Venant equations by ignoring part of the terms from the momentum equation to be excluded from the modeling. Thus, various research models emerged, including the kinematic model [1], [2], [3], the diffusion model [4], and the Keskin model [5], [6]. Meanwhile, other researchers developed certain numerical methods for solving Saint Venant's equations without simplification. Among the numerical methods used include the characteristic method [7], [8], the finite difference method [9], [10], [11], the finite element method [12], [13], the finite volume method [14], [15], and the finite volume method on the grid staggered [16], [17].

Using the complete Saint Venant equations without simplification to describe unsteady flow behavior in an open channel will give reliable results if the underlying assumptions are fulfilled. However, this model requires a rather complex solution method and a relatively large amount of data characterizing the channel shape and flow conditions [18]. For these reasons, we proposed using simplified Saint Venant equations to obtain a model that requires less input information, a simpler numerical method, and only applies to prismatic channel shapes.

In this research, the simulation of flow routing in the prismatic channel was carried out using the Saint Venant equations with a simplification called the Keskin model. Unlike other simplification models, the simulation results from the Keskin model have high compatibility with the simulation results from the model without simplification [5], do not require a lot of computation time, and can be solved by relatively simple numerical methods.

\section{METHOD}

\subsection{Governing Equation}

The mathematical model that can be used to describe the flow behavior in a channel is the Saint Venant equations [7]. This equation is composed of two simultaneous equations, namely the continuity equation and the momentum equation. The Saint Venant equations can be written as

$$
\begin{gathered}
\frac{\partial A}{\partial t}+\frac{\partial Q}{\partial x}=0 \\
\frac{\partial Q}{\partial t}+\frac{\partial}{\partial x}\left(\frac{Q^{2}}{A}\right)+g A \frac{\partial h}{\partial x}+g A\left(S_{f}-S_{0}\right)=0
\end{gathered}
$$

where $A$ is the wet cross-sectional area, $Q$ is the discharge, $h$ is the water level, $S_{f}$ is the slope of friction, $S_{0}$ is the slope of the bottom channel, $g$ is the acceleration due to gravity, $t$ is coordinate of time, and $x$ is the coordinate of distance.

For flood routing problems in a prismatic channel (it is assumed that the channel width $b$ is constant) with a rectangular section, the wet cross-sectional area $A$ can be written as

$$
A=b h \text {. }
$$


Equation (3) is derived concerning $x$, then we obtain

$$
\frac{\partial A}{\partial x}=b \frac{\partial h}{\partial x}
$$

Substitute equation (4) into equation (2) so we obtain

$$
\frac{\partial Q}{\partial t}+2 \frac{Q}{A} \frac{\partial Q}{\partial x}+\left(\frac{g A}{b}-\frac{Q^{2}}{A^{2}}\right) \frac{\partial A}{\partial x}+g A\left(S_{f}-S_{0}\right)=0
$$

When the flow occurs in an open channel, due to the roughness of the walls and bottom of the channel as a barrier where the flow is located, there will be a resistance flow from upstream to downstream which will have a direct effect on the magnitude of the velocity. Calculation of flow velocity through an open channel can only be done using empirical formulas because many variables change. In this regard, experts such as Chezy, Manning, or Strickler provide empirical formulas built on a steady uniform flow formula. If we choose the Manning formula, then this formula represents the resistance of flow can be written as

$$
S_{f}=\frac{n^{2} u^{2}}{R^{4 / 3}}
$$

where $n$ denotes the Manning coefficient, $R$ denotes the hydraulic radius, and $u$ denotes the velocity.

For a channel with a rectangular cross-section, the following relationships apply

$$
\begin{gathered}
R=\frac{A}{P}, \\
P=2 h+b,
\end{gathered}
$$

with $P$ denotes the wet perimeter of the cross-section. Furthermore, equations (6), (7), and (8) are derived partially concerning $x$, obtained

$$
\begin{gathered}
\frac{\partial P}{\partial x}=2 \frac{\partial h}{\partial x}, \\
\frac{\partial R}{\partial x}=\frac{1}{P}\left(1-\frac{2 A}{b P}\right) \frac{\partial A}{\partial x} \\
\frac{\partial u}{\partial x}=\frac{2}{3} \frac{1}{n} R^{-\frac{1}{3}} S_{f}^{\frac{1}{2}} \frac{\partial R}{\partial x}+\frac{1}{2} \frac{1}{n} R^{\frac{2}{3}} S_{f}^{-\frac{1}{3}} \frac{\partial S_{f}}{\partial x} .
\end{gathered}
$$

According to [5], the value of $\frac{\partial S_{f}}{\partial x}$ is very small when compared to the values of other terms, so that the second term on the right side of equation (11) can be ignored. Therefore, Equation (11) can be rewritten as

$$
\frac{\partial u}{\partial x}=\frac{2}{3} \frac{1}{n} R^{-\frac{1}{3}} S_{f}^{\frac{1}{2}} \frac{\partial R}{\partial x}
$$

In a steady flow, the discharge is defined as $Q=A u$. If it is derived partially concerning $x$, it is obtained

$$
\frac{\partial Q}{\partial x}=A \frac{\partial u}{\partial x}+u \frac{\partial A}{\partial x} .
$$


Then substitute equations (9), (10), and (12) into equation (13) and be rearranged of the equation, we obtain

$$
\frac{\partial A}{\partial x}=\frac{1}{\frac{Q}{A}\left(\frac{5}{3}-\frac{4 R}{3 b}\right)} \frac{\partial Q}{\partial x}
$$

Next, substitute equation (14) into equation (5) and be rearranged of the equation, we get

$$
\frac{\partial Q}{\partial t}+\alpha \frac{\partial Q}{\partial x}+\beta=0
$$

where

$$
\alpha=\left(2 \frac{Q}{A}+\frac{\frac{g A}{b}-\frac{Q^{2}}{A^{2}}}{\frac{Q}{A}\left(\frac{5}{3}-\frac{4 R}{3 b}\right)}\right)
$$

and

$$
\beta=g A\left(S_{f}-S_{0}\right)
$$

The momentum equation has two variables related to the cross-sectional area and the discharge of the channel. Therefore, Equations (1) and (15) can be solved using different numerical methods until they follow the initial and boundary conditions.

\subsection{Numerical Method}

The Saint Venant equations (1) and (15) will be solved numerically using the finite difference method. With this method, the equation will be converted into a different equation that only applies to specific points in the domain of the solution. Since these equations contain the independent variables $x$ and $t$, an approximation of the difference equation is made by creating the number of the grid on the $x-t$ plane.

If the partial differential equation has an exact solution $f(x, t)$, then the differential equation will have an approximate solution of $f\left(x_{i}, t^{k}\right)$. Here, any function $f(x, t)$ and its partial derivatives will be discretized by an explicitly different method (forward time and backward space) using the following rules.

$$
\begin{aligned}
& f(x, t) \approx f\left(x_{i}, t^{k}\right)=f_{i}^{k}, \\
& \left.\frac{\partial f(x, t)}{\partial t} \approx \frac{\partial f}{\partial t}\right|_{i} ^{k}=\frac{f_{i}^{k+1}-f_{i}^{k}}{\Delta t}, \\
& \left.\frac{\partial f(x, t)}{\partial x} \approx \frac{\partial f}{\partial x}\right|_{i} ^{k}=\frac{f_{i}^{k}-f_{i-1}^{k}}{\Delta x},
\end{aligned}
$$

where $x$ and $t$ are the length of the interval in the direction $x$ and the length of the interval in the direction $t$, respectively. Substitute equations (18), (19), (20) into the momentum equation (15) and the continuity equation (1), we get

$$
\begin{gathered}
Q_{i}^{k+1}=Q_{i}^{k}-\frac{\Delta t}{\Delta x}\left(\alpha_{i}^{k}\right)\left(Q_{i}^{k}-Q_{i-1}^{k}\right)-\beta_{i}^{k} \Delta t, \\
A_{i}^{k+1}=A_{i}^{k}-\frac{\Delta t}{\Delta x}\left(Q_{i}^{k+1}-Q_{i-1}^{k+1}\right),
\end{gathered}
$$


where

$$
\begin{gathered}
\alpha_{i}^{k}=2 \frac{Q_{i}^{k}}{A_{i}^{k}}+\frac{\frac{g A_{i}^{k}}{b}-\left(\frac{Q_{i}^{k}}{A_{i}^{k}}\right)^{2}}{\frac{Q_{i}^{k}}{A_{i}^{k}}\left(\frac{5}{3}-\frac{4_{i}^{R_{i}^{k}}}{3 b}\right)^{k}} \\
\beta_{i}^{k}=g A_{i}^{k}\left(S_{f_{i}}^{k}-S_{0}\right) .
\end{gathered}
$$

From the explanation above, it can be seen that each pair of values of $\alpha_{i}^{k}$ and $\beta_{i}^{k}$ can be calculated from Equations (23) and (24) using the initial condition data and the boundary conditions that are known at the beginning $(i, k)$ so that the value $Q_{i}^{k+1}$ can be obtained from Equation (21). Finally, using the value $Q_{i}^{k+1}$, the value $A_{i}^{k+1}$ can be calculated from Equation (22). This technique will be repeated sequentially for the values of $(i, k)$.

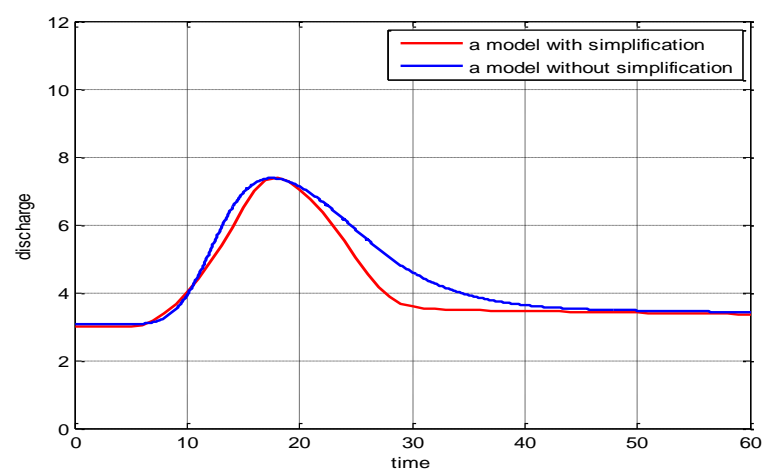

Figure 1. Discharge from the staggered numerical model (blue) and the simplified model (red) for $x=600 \mathrm{~m}$.

Before being used for simulation, it is necessary to test it first to ensure that the proposed numerical scheme can be applied. The proposed model is validated with a staggered numerical model [17]. The validation results show (see Figure 1) that the simulation results of the two models generally have a good agreement. These slight differences take place because of the simplifications considered in the proposed model.

\section{RESULT AND DISCUSSION}

The numerical schemes from equations (21) and (22) will be applied to flow routing in a prismatic channel. A prismatic channel with a rectangular cross-section is fed by water from the upstream direction. By utilizing the discharge data that enters the prismatic channel, the downstream area will observe changes in the behavior of two water flow variables, namely discharge and water level elevation. The general components used for numerical simulations are as follows: channel length $L=$ $2000 \mathrm{~m}$, constant channel width $b=5 \mathrm{~m}$, channel base slope $S_{f}=0.0005$, Manning roughness coefficient $n=0.0138$, gravitational acceleration $g=9,81 \mathrm{~m} / \mathrm{s}^{2}$, space step $\Delta x=1 \mathrm{~m}$, time step $\Delta t=0.1 \mathrm{~s}$ and the simulation is carried out for 60 units of time, $T=60 \mathrm{~s}$.

The next presentation is a simulation of water flow routing in a prismatic channel due to variations in the incoming inflow hydrograph, namely triangular, trapezoidal, and curvature. Then investigate the behavior of the water flow variable that will be observed in the form of discharge at certain locations in the downstream area, for example, at $x=600 \mathrm{~m}$. 


\subsection{Triangular Inflow Hydrograph}

A prismatic channel with a rectangular cross-section is fed by water from the upstream direction. From the upstream direction, a triangular inflow hydrograph is recorded into the channel with the following data,

$$
Q(0, t)=\left\{\begin{array}{ccc}
3+\frac{9}{10} t & \text { for } & 0 \leq t<10 \\
12-\frac{9}{10}(t-10) & \text { for } & 10 \leq t<20 \\
3 & \text { for } & t \geq 20
\end{array}\right.
$$

where the initial condition is $Q(x, 0)=3 \mathrm{~m}^{3} / \mathrm{s}, A(x, 0)=3 \mathrm{~m}^{3} / \mathrm{s}$. The hydrograph inflow profile that enters the prismatic channel can be seen in Figure 1.

Figure 2 shows the discharge quantity that will gradually enter the prismatic channel over $20 \mathrm{~s}$, $0<t \leq 20 \mathrm{~s}$. Initially, the discharge entering the prismatic channel is relatively small, which is $Q=3 \mathrm{~m}^{3} / \mathrm{s}$. As time increases, the incoming debit to fill the channel gets bigger until it reaches its peak when $t=10 \mathrm{~s}$, which is $Q=12 \mathrm{~m}^{3} / \mathrm{s}$. After that, the incoming debit gradually decreases until no more debit enters the channel, and this happens when $t=20 \mathrm{~s}$. Based on upstream discharge data like this, in the following discussion, several simulation results will be displayed regarding changes in the behavior of water flow variables in the form of discharge (outflow hydrograph) in the downstream area.

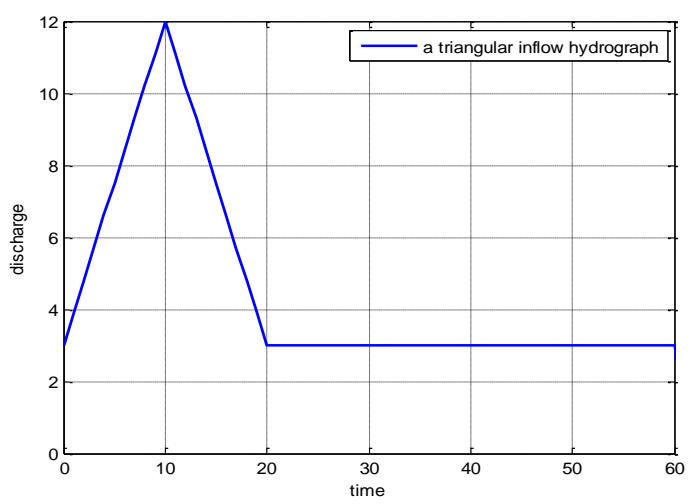

Figure 2. The hydrograph inflow profile is triangular that enters a prismatic channel.

The simulation results of changes in water flow variables in the form of hydrograph outflow along the channel can be seen in Figure 3. The figure shows an animation of downstream flow movements for a time of $0<t \leq 60 \mathrm{~s}$ due to the triangular hydrograph inflow that enters the channel for $0<t \leq 20 \mathrm{~s}$.

From Figure 3, it can be seen that the discharge that enters the channel will propagate downstream for each unit of time, with the quantity of discharge that is getting smaller and smaller until the effect of the hydrograph inflow is gone. The hydrograph inflow will experience damping along the canal due to the influence of friction between the water and the bottom and walls of the canal. The farther from the source of discharge, the greater the shrinkage of the discharge. 


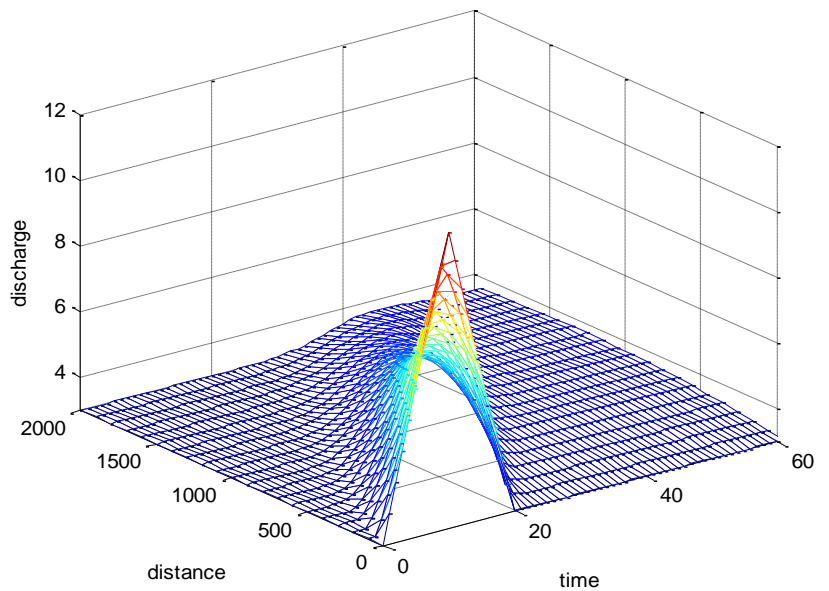

Figure 3. Discharge profile due to a triangular hydrograph inflow.

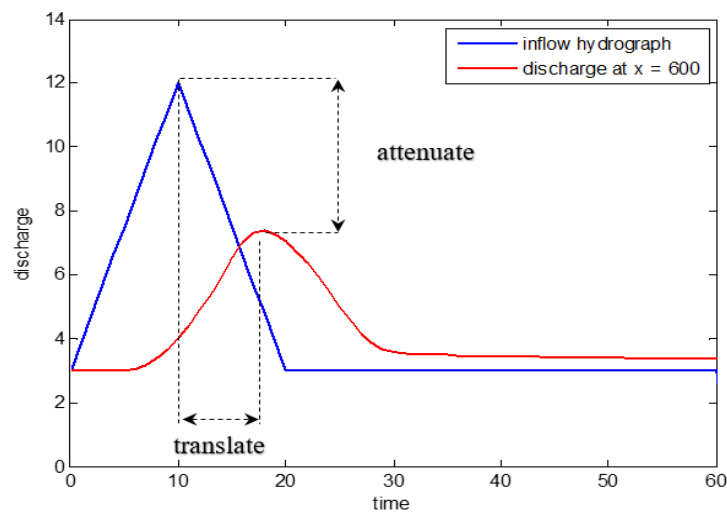

Figure 4. A comparison between a triangular hydrograph inflow and discharge at $x=600 \mathrm{~m}$ : indicates a decrease in peak discharge.

Figure 4 is presented a triangular hydrograph inflow and a hydrograph outflow observed at a location $600 \mathrm{~m}$ from the upstream. From the figure, it can be seen that the maximum discharge has decreased from $Q=12 \mathrm{~m}^{3} / \mathrm{s}$ to $Q=7.38 \mathrm{~m}^{3} / \mathrm{s}$, and the time of the maximum discharge has also shifted from $t=10 \mathrm{~s}$ to $t=18 \mathrm{~s}$.

\subsection{Trapezoidal Inflow Hydrograph}

A prismatic channel with a rectangular cross-section is fed by water from the upstream direction. From the upstream direction, a trapezoidal-shaped hydrograph inflow is recorded into the channel with the following data,

$$
Q(0, t)=\left\{\begin{array}{ccc}
3+\frac{9}{10} t & \text { for } & 0 \leq t<10 \\
12 & \text { for } & 10 \leq t<15 \\
12-\frac{9}{5}(t-15) & \text { for } & 15 \leq t<20 \\
3 & \text { for } & t \geq 20
\end{array}\right.
$$

where the initial condition is $Q(x, 0)=3 \mathrm{~m}^{3} / \mathrm{s}, A(x, 0)=3 \mathrm{~m}^{3} / \mathrm{s}$. The hydrograph inflow profile that enters the prismatic channel can be seen in Figure 5 . Figure 5 shows the quantity of discharge 
that will enter the channel gradually over $20 \mathrm{~s}$. Initially, the incoming discharge is small at $Q=3 \mathrm{~m}^{3} / \mathrm{s}$, as time goes on, the incoming discharge gets bigger until it reaches its peak when $t=10 \mathrm{~s}$, is $Q=12$ $\mathrm{m}^{3} / \mathrm{s}$. The discharge input of $Q=12 \mathrm{~m}^{3} / \mathrm{s}$ is maintained to fill the channel up to when $t=15 \mathrm{~s}$. After that, the incoming discharge has decreased to $Q=3 \mathrm{~m}^{3} / \mathrm{s}$ when $t=20 \mathrm{~s}$.

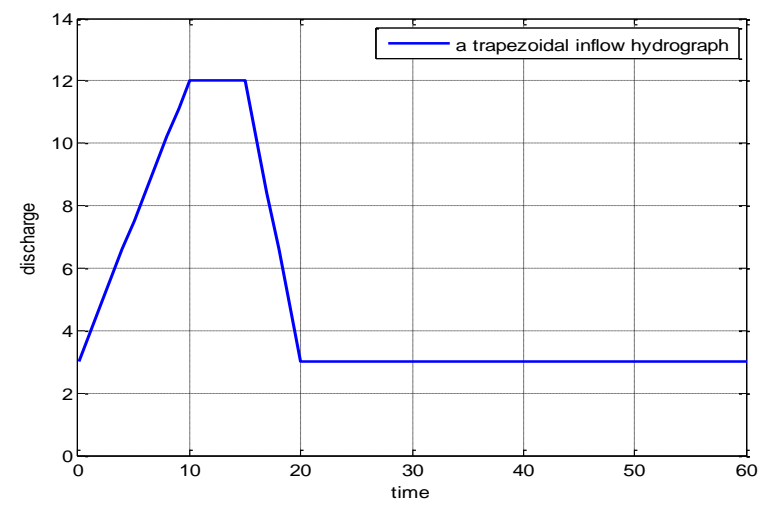

Figure 5. The hydrograph inflow profile is trapezoidal that enters a prismatic channel.

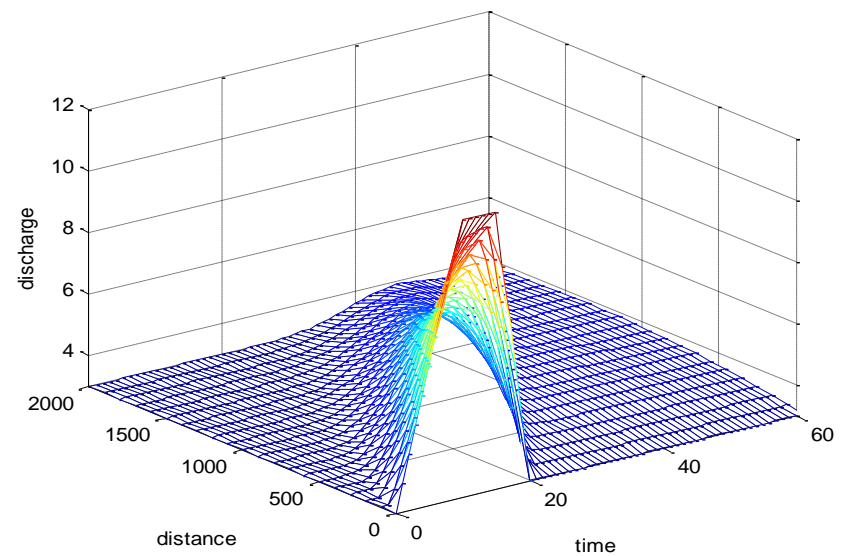

Figure 6. Discharge profile due to a trapezoidal hydrograph inflow.

Figure 6 shows that the discharge entering the channel will propagate downstream for each unit of time. The discharge quantity decreases from time to time until the influence of the incoming hydrograph flow disappears. The amount of debit depreciation depends on the distance from the source of the debit. The further away from the source, the greater the shrinkage.

Figure 7 is presented a trapezoidal inflow hydrograph and a hydrograph outflow observed at a location $600 \mathrm{~m}$ from the upstream. From the figure, it can be seen that the maximum discharge has decreased from $Q=12 \mathrm{~m}^{3} / \mathrm{s}$ to $Q=8.45 \mathrm{~m}^{3} / \mathrm{s}$ and the time of maximum discharge has also shifted from $t=10 \mathrm{~s}$ to $t=22 \mathrm{~s}$. This maximum discharge shrinkage and time-shift occurred at each location along the channel. 


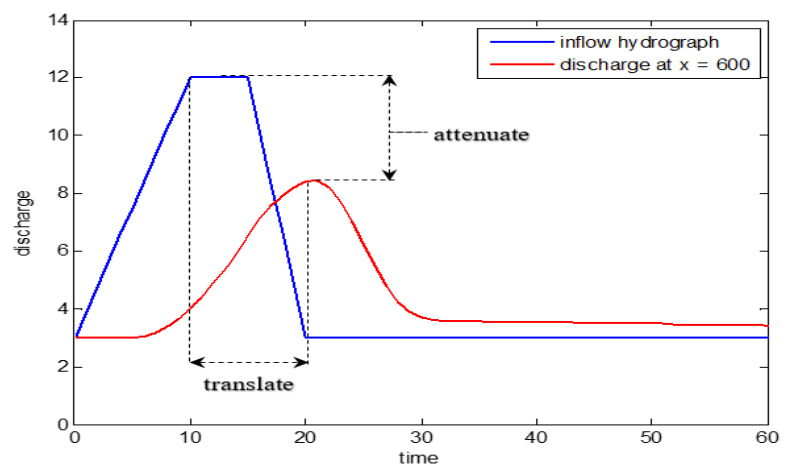

Figure 7. A comparison between trapezoidal hydrograph inflow and discharge at $x=600 \mathrm{~m}$ : indicates a decrease in peak discharge.

\subsection{Curvature Inflow Hydrograph}

A prismatic channel with a rectangular cross-section is fed by water from the upstream direction. From the upstream direction, a curvature inflow hydrograph is recorded into the channel with the following data,

$$
Q(0, t)=\left\{\begin{array}{clc}
18 / 4 \sin \left(\frac{\pi t}{10}-\frac{\pi}{2}\right)+\frac{30}{4}, & \text { for } & 0 \leq t<10 \\
18 / 4 \cos \left(\frac{1.4 \pi t}{14}-\frac{\pi}{100}\right)+\frac{30}{4}, & \text { for } & 10 \leq t<20 \\
3, & \text { for } & t \geq 20
\end{array}\right.
$$

where the initial condition is $Q(x, 0)=3 \mathrm{~m}^{3} / \mathrm{s}, A(x, 0)=3 \mathrm{~m}^{3} / \mathrm{s}$. The hydrograph inflow profile that enters the prismatic channel can be seen in Figure 8. Figure 8 shows the amount of discharge that will enter the channel gradually over $20 \mathrm{~s}$. Initially, the incoming discharge is small at $Q=3 \mathrm{~m}^{3} / \mathrm{s}$; over time, the incoming discharge gets bigger until it reaches its peak, namely $Q=12 \mathrm{~m}^{3} / \mathrm{s}$ when $t=$ $10 \mathrm{~s}$. After that, the incoming discharge decreases to $Q=3 \mathrm{~m}^{3} / \mathrm{s}$ when $t=20 \mathrm{~s}$.

From Figure 9, it can be seen that the discharge that enters the channel will propagate downstream for each unit of time, with the quantity of discharge that is getting smaller and smaller until the effect of the hydrograph inflow is gone. The hydrograph inflow will experience damping along the canal due to the influence of friction between the water and the bottom and walls of the canal. The farther from the source of discharge, the greater the shrinkage of the discharge.

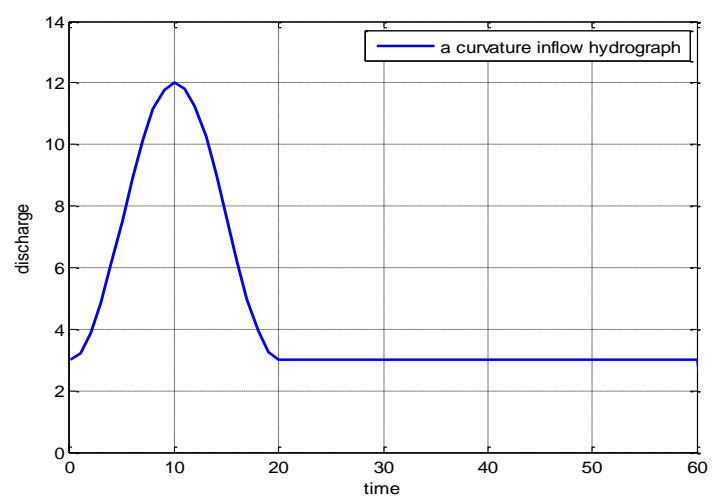

Figure 8. The hydrograph inflow profile is a curvature in shape that enters a prismatic channel. 


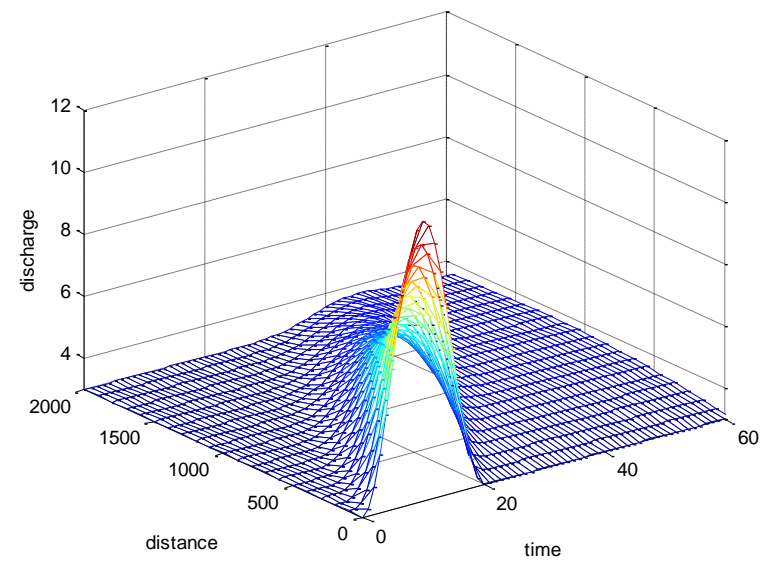

Figure 9. Discharge profile due to a curvature hydrograph inflow.

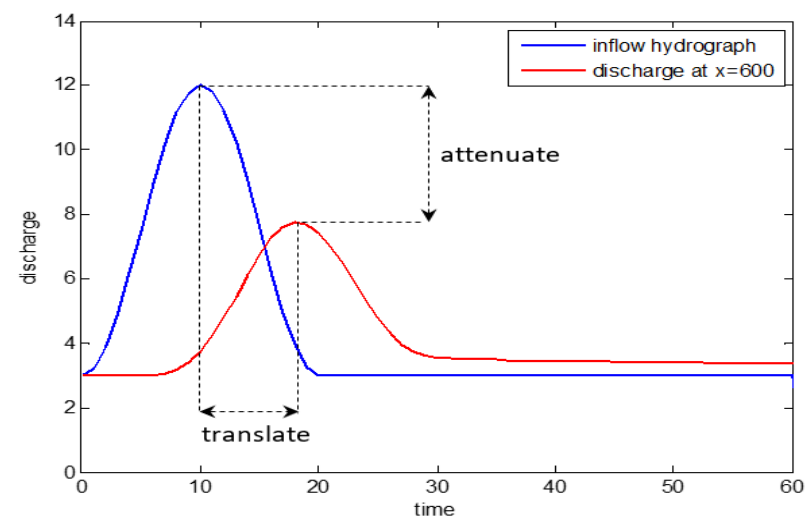

Figure 10. A comparison between curvature hydrograph inflow and discharge at $x=600 \mathrm{~m}$ : indicates a decrease in peak discharge.

Figure 10 is presented a triangular hydrograph inflow and a hydrograph outflow observed at a location $600 \mathrm{~m}$ from the upstream. From the figure, it can be seen that the maximum discharge has decreased from $Q=12 \mathrm{~m}^{3} / \mathrm{s}$ to $Q=7.78 \mathrm{~m}^{3} / \mathrm{s}$ and the time of the maximum discharge has also shifted from $t=10 \mathrm{~s}$ to $t=19 \mathrm{~s}$.

\section{CONCLUSION}

The Saint Venant equations are mathematical models that can describe the phenomenon of water flow in an open channel. The model is built based on two natural laws: the law of conservation of mass and the law of conservation of momentum. These two laws are commonly expressed in mathematical equations known as the continuity equation and the momentum equation.

Based on the observation of the numerical simulation results in this research, it can be concluded that the hydrograph inflow that enters the prismatic channel will experience shrinkage along the channel due to friction between the water flow and the bottom and walls of the channel. The farther from the discharge source, the greater the shrinkage of the water flow variable. For observations at a specific location, the size of the variable quantity of water flow depends on the size of the incoming hydrograph inflow quantity.

For the same observation location, the greater volume of the inflow hydrograph, the greater the outflow hydrograph. If we sort from the smallest: the triangular hydrograph produces a peak discharge 
$Q=7.38 \mathrm{~m}^{3} / \mathrm{s}$ at time $t=18 \mathrm{~s}$, the curvature hydrograph produces a peak discharge $Q=7.78 \mathrm{~m}^{3} / \mathrm{s}$

at time $t=19 \mathrm{~s}$, and the trapezoidal hydrograph produces a peak discharge $Q=8.45 \mathrm{~m}^{3} / \mathrm{s}$ at time $t=22 \mathrm{~s}$.

\section{REFERENCES}

[1] T. S. Nguyena, T. A Luongb, H. D. Luongb and H. T. Tranc, "A finite element onedimensional kinematic wave rainfall-runoff model," Pacific Science Review A: Natural Science and Engineering, 18, pp. 233-240, 2016.

[2] C. W. Tsai, "Applicability of kinematic, noninertia, and quasi-steady dynamic wave models to unsteady flow routing," Journal of Hydraulic Engineering, 129(8), 613-627, 2003 [doi:10.1061/(ASCE)0733-9429129:8(613)].

[3] A.O. Ogunlela and B. Adelodum, "Kinematic parameter for Asa River Routing," International Journal of Environmental and Ecological Engineering, vol: 8, No:5, pp. 346-349, 2014.

[4] G. T. Wang, S. Chen, J. Boll and V. P. Singh, "Nonlinear convection-diffusion equation with mixing-cell method for channel flood routing," Journal of Hydrologic Engineering, 8(5), 259-265, 2003 [doi:10.1061/(ASCE)1084-0699(2003)8:5(259)].

[5] M. E. Keskin and N. A. Agiralioglu, "Simplified Dynamic Model for Flood Routing in Rectangular Channels," Journal of Hydrology, v. 202, p. 302-314, 1997.

[6] B. A. Sulistyono and L. H. Wiryanto, "Investigation of Flood routing by a Dynamic Wave Model in Trapezoidal Channels," AIP Conference Proceedings, 1867, 020020, 2017, doi: 10.1063/1.4994423.

[7] F. P. Cunge, F. M. Holly and A. Jr. Verwey, "Practical Aspects of Computational River Hydraulics," Pitman Advanced Publishing Program, 1980.

[8] M. H. Chaudhry,"Open-Channel Flow," Second Edition, Springer Science+Business Media, 2008, LLC, New York, USA.

[9] A. O. Amien and C. S. Fang,"Implicit Flood Routing in Channel Network," Journal Hydraulic Division, ASCE, 96, 918-926, 1970.

[10] R. Barati, S. Rahimi and G. H. Akbari, "Analysis of Dynamic Wave Model for Flood Routing in Natural Rivers," Water Science and Engineering, 5(3), 243-258, 2012.

[11] E. Retsinis, E. Daskalaki, and P. Papanicolaou, "Dynamic flood wave routing in prismatic channels with hydrologic methods," Journal of Water Supply: Research and Technology-Aqua, jws 2019091, 2019.

[12] Y. Zhang, "Simulation of Open Channel Network Flows Using Finite Element Approach," Communications in Nonlinear Science and Numerical Simulation, 10(5), 467-478, 2005.

[13] A. L. Qureshi, A. Mahessar and A. Baloch, "Verification and Application of Finite Element Model Developed for Flood Routing in Rivers," World Academy of Science, Engineering and Technology International Journal of Environmental, Earth Science and Engineering, Vol. 8, No. 2, 2014.

[14] W. Lai and A. A. Khan, "Numerical solution of the Saint-Venant equations by an efficient hybrid finite-volume/finite-difference method," Journal of Hydrodynamics, Volume 30, Issue 2, pp 189-202, 2018.

[15] S. Mungkasi, "Adaptive Finite Volume Method for the Shallow Water Equations on Triangular Grids, " Adv. Math. Phys., vol. 2016, no. 7528625, 2016, pp.1-7. DOI: 10.1155/2016/7528625

[16] B. A. Sulistyono, L. H. Wiryanto and S. Mungkasi, "A Staggered Method for Simulating Shallow Water Flows along Channels with Irregular Geometry and Friction, "International Journal on Advanced Science, Engineering and Information Technology (IJASEIT), Vol. 10, Issue 3, 2020, doi:10.18517/ijaseit.10.3.7413. 
[17] B. A. Sulistyono and L. H. Wiryanto, "A Staggered Method for Numerical Flood Routing in Rectangular Channels", Advances and Applications in Fluid Mechanics, Vol. 23, Number 2, Pages 171-179 ISSN: 0973-4686, 2019.

[18] R. Szymkiewics, "Numerical Modeling in Open Channel Hydraulics," Water Science and Technology Library, Vol. 83, Springer, 2010. 